\title{
ALVES \& CIA E SENHORA: ARRANJOS NUPCIAIS, CONTRATOS SOCIAIS
}

\author{
Talita Papoula* \\ O casamento dos pequenos burgueses \\ Ele faz o noivo correto \\ E ela faz que quase desmaia \\ Vão viver sob o mesmo teto \\ Até que a casa caia \\ Até que a casa caia \\ Ele é o empregado discreto \\ Ela engoma o seu colarinho \\ Vão viver sob o mesmo teto \\ Até explodir o ninho \\ Até explodir o ninho \\ $[\ldots]$ \\ Ele tem um caso secreto \\ Ela diz que não sai dos trilhos \\ Vão viver sob o mesmo teto \\ Até casarem os filhos \\ Até casarem os filhos
}

Chico Buarque

Mikhail Bakhtin em Problemas da Poética de Dostoievski defende a teoria de que todo discurso é uma realização social, possível apenas quando três elementos essenciais estão presentes: um $e \boldsymbol{u}$-enunciador, um texto-enunciado e um tu-enunciatário. Neste sentido, o que Bakhtin está a afirmar é que todo discurso é necessariamente dialógico, já que se constitui a partir da interação entre o produtor e o receptor que, pautados numa mensagem textual oral ou escrita, estabelecem entre si um diálogo. Ainda a esse respeito, Jean-Paul Sartre em Que é Literatura? afirma que é «o esforço conjugado do autor com o leitor que fará surgir esse objeto concreto e imaginário que é a obra do espírito» (SARTRE, 2004: 37). No mesmo livro, Sartre explica ainda que entre autor e leitor existe um pacto de liberdade, através do qual o escritor cria livremente e apela ao leitor que retribua essa liberdade de criação, empenhando-se na interpretação da mensa-

" Mestranda em Literatura Portuguesa pela UFRJ. Contemplada com Bolsa de Pesquisa da Fundação Calouste Gulbenkian, desenvolveu o presente projeto como licencianda em Português-Literaturas, junto à Cátedra Jorge de Sena, sob orientação da professora doutora Monica Figueiredo. 
gem. Isto, por sua vez, nos remete a Roland Barthes no seu texto emblemático que é a Aula inaugural no Collège de France, texto em que o estudioso defende a literatura como o único discurso que está fora do eixo do poder. A literatura, na perspectiva barthesiana, seria aquela que utiliza a linguagem como um instrumento de trapaça, e uma trapaça salutar, já que rompe com o poder inerente a qualquer discurso, assegurando, assim, a tal liberdade de que tratava Sartre.

Ao mencionarmos Bakhtin, Sartre ou Barthes, pretendemos nada menos que estabelecer um «vaivém dialético» ${ }^{1}$, através do qual as idéias aqui desenvolvidas não constituirão apenas um texto, e sim um "discurso» " ${ }^{2}$ Sendo a Literatura um processo constante de ressignificação, necessitamos desde já da ação dos enunciatários para revisitar, no presente, enunciados há muito produzidos por enunciadores que, a seu tempo, tentaram fazer de seus textos efetivos discursos literários. Estamos tratando da releitura crítica de Senhora e Alves \& Cia, obras produzidas, respectivamente, por José de Alencar, no Brasil, e Eça de Queirós, em Portugal, durante o século XIX. Pretende-se, aqui, comparar as duas obras e expor as semelhanças e as diferenças que regeram a escolha - audaciosa, talvez, mas a nosso ver pertinente - de cada uma delas para compor nosso ensaio «Alves \& Cia e Senhora: arranjos nupciais, contratos sociais».

Representações sociais indiscutíveis de seu tempo histórico, os textos literários constituem, para além disso, evidências de uma escritura que transgride o uso normativo da língua, oferecendo-lhe a surpresa de uma liberdade de que só a literatura é capaz. Se Alencar e Eça criam discursos que reavaliam criticamente os «corpos sociais» históricos, não são menos os criadores de "corpos textuais» transgressores que desarticulam modelos lingüísticos e ideológicos impostos pela norma.

Alves \& Cia e Senhora ${ }^{3}$ repetem, até certo ponto, enredos que, apesar de diferentes, se pautam sobre um tema característico do século XIX: a íntima relação entre negociações comerciais e compromissos matrimoniais. Tanto no Portugal oitocentista, quanto no Rio de Janeiro do Segundo Império, a ideologia capitalista não se manifestava somente nas relações de trabalho, mas também no espírito mercantil dos relacionamentos matrimoniais. Frente a essa realidade, Eça de Queirós e José de Alencar produziram discursos ficcionais que evidenciam suas posições críticas. De perto, os escritores perceberam que as sociedades financeiras e os acordos matrimoniais eram, na verdade, um corpo único onde se espelhavam os valores do amor burguês.

Alves \& Cia (1887) conta a história de um «possível» caso de adultério entre Ludovina, esposa de Godofredo Alves, e Machado, sócio de Godofredo. A descoberta do provável caso por Godofredo provoca a dissolução do casamento e da sociedade comercial que os unia, fazendo com que os sócios intentem se bater em duelo. No entanto, após decisão consensual dos amigos de Godofredo, o atormentado marido conclui que, de fato, não houvera adultério e que tudo 
não passara de uma «brincadeira». O compromisso amoroso é assim reatado e, com ele, a sociedade financeira é mantida.

Senhora (1875), por sua vez, narra a relação matrimonial de Aurélia e Fernando Seixas, um típico casamento por conveniências. Aurélia se apaixonara por Seixas nos tempos em que era uma moça pobre, quando não tinha dote valioso a oferecer e, por isso, fora abandonada pelo homem que amava. Ao enriquecer, no entanto, Aurélia, num ato de suprema vingança, compra como marido o próprio Seixas. Estabelece-se entre eles uma relação caracteristicamente comercial, cabendo aos cônjuges não o enlace amoroso, mas o cumprimento de um contrato. Só ao fim de um longo martírio duplamente experimentado, vencida pelo amor, Aurélia se rende a Fernando, e os noivos, enfim, consumam o casamento.

Que de uma ligação «híbrida» entre amor e lucro as obras tratam, isso é claro e pode ser percebido a partir de qualquer leitura. Que haja uma aproximação entre um escritor dito romântico e outro realista, isso pode ser explicado por serem o Romantismo e o Realismo momentos estéticos oriundos de uma mesma factualidade histórica. O que nos interessa, contudo, é o modo como José de Alencar e Eça de Queirós encaram diferentemente os fatos, como cada um se posiciona criticamente diante da sociedade burguesa que retratam. Se é verdade que há crítica em ambos os discursos, é bem verdade também que a intensidade, assim como o tratamento dado ao conceito de traição, é diferente em cada narrativa.

Em Senhora, o índice já ilustra o interesse alencariano de questionar as bases em que as relações «amorosas» estavam calcadas. Dividindo os capítulos do livro pelos subtítulos «Preço», "Quitação», «Posse»e "Resgate», o autor está a afirmar que os acordos matrimoniais nada mais são que transações comerciais. Na primeira parte, intitulada "Preço", o que se vê é o poder que têm os cifrões para negociar não só bens materiais como também sentimentos. Com dinheiro, Aurélia compra a vingança do abandono sofrido no passado, e seu preço é a mortificação do amor; por dinheiro, Seixas vende a própria dignidade, comprando com ela dor e humilhação. Resignados em ser o que são - ela «uma mulher traída», ele «um homem vendido» - o contrato entra em vigor. Ajustados os preços, passa-se à «Quitação». A Fernando cabe servir com alegria; a Aurélia cabe o desfrute da transação: um casamento socialmente feliz e um marido servilmente infeliz. Enfim, na última parte, chamada "Resgate», o que ocorre é o fim do sofrimento, garantido pela vitória do amor, sob os auspícios da opção de uma Aurélia agora assumidamente apaixonada e de um Fernando Seixas enfim redimido. Num final romanticamente feliz, «As cortinas cerraram-se, e as auras da noite, acariciando o seio das flores, cantavam o hino misterioso do santo amor conjugal» $(S$, p. 183).

Se as três primeiras partes evidenciam uma crítica de Alencar ao amor como negócio, a última nos encaminharia, seguindo esse raciocínio, a uma «contracrítica», já que do casamento de Aurélia e Fernando, o amor acaba saindo 
vencedor. Nesse sentido, a instituição criticada durante toda a narrativa é a mesma que possibilita a realização amorosa no final da trama, o que nos levaria a crer que, talvez, para Alencar, o casamento por conveniência não seria grande mal, desde que houvesse amor. Sobre isso dirá Afonso Romano de Sant'Anna:

Nessa obra abre-se a contradição do narrador: pretendendo denunciar o «mercado matrimonial» organizado pela sociedade burguesa ele termina por revalidar todos os valores da sociedade. Os personagens se encontram depois de preencher os papéis positivos que a sociedade romântica estatuiu. Eles sonham e se realizam dentro da comunidade que o autor quis censurar. (Sant'Anna, 1990: 21)

Sem invalidar o romântico desfecho - não esquecendo, aliás, que Alencar era um escritor do Romantismo e, como tal, tinha a intenção idealista de priorizar o amor como valor moral - vale atentar, contudo, para o fato de que praticamente toda a história de Senhora é escrita privilegiando a crítica aos valores burgueses, sendo apenas o último parágrafo destinado ao resgate do amor. Quase toda a narrativa é construída graças ao desejo de vingança, à experiência da dor, da humilhação e do desprezo, sempre vinculados ao uso do dinheiro que rege as relações sentimentais. O amor ocupa, portanto, poucas linhas, e com o desaparecimento dos verdadeiros motores daquela narrativa parece que não há mais sobre o que escrever: é o fim da própria narrativa. Poderíamos sugerir, por isso, que Alencar terá dado a Senhora o fim que deu para se manter de certo modo fiel ao ideário da escola à qual se vinculara - o Romantismo. Sobre isso, afirmou Antonio Candido:

[...] em Senhora, do grande amor de Aurélia com a vergonhosa transação que põe Fernando à sua mercê, [...] só pode haver um happy-end graças a um expediente imposto à coerência da narrativa, [...] que deixa[m] um sulco de melancolia no espírito do leitor. (CANDIDO, 2002: 206)

Se observarmos, no entanto, atenciosamente o título, perceberemos que há ali uma chave a não ser, por coerência, desprezada, apontando no romance uma leitura da superação da "contracrítica» pela crítica. Porque se, para Alencar, o amor é o mesmo, esse sentimento que faz Aurélia se humilhar e dizer a Fernando: «-Aquela que te humilhou, aqui a tens abatida, no mesmo lugar onde ultrajou-te, nas iras de sua paixão. Aqui a tens implorando teu perdão e feliz porque te adora, como o senhor de sua alma.» (S, p. 182), isto significará que ele, o amor, é antes aquele que serve e não o que senhoreia. Nesse sentido, se o amor fosse de fato o ideal do livro, caberia a Alencar intitulá-lo talvez Serva, mas não Senhora, já que por Senhora lê-se aquela que detém o poder e o dinheiro, utilizando-os na negociação do contrato matrimonial. 
Contudo, embora defendamos a prevalência da crítica feita por Alencar, temos de convir que, de fato, o enredo é selado com a redenção do amor. Entretanto, discordando da contradição defendida por Affonso Romano, ousaríamos afirmar que em Senhora o que se tem é uma crítica coerente e compatível com os valores morais da época. Se é verdade que os noivos terminam a narrativa felizes, por meio da mesma instituição censurada durante todo o enredo, também é verdade que simbolicamente Aurélia quebra e desfaz o antigo acordo matrimonial - que afinal só existira verbalmente - antes de se entregar à experiência vivida do amor. Como se aquela instituição fadada às alianças constrangidas pelo poder do dinheiro ali acabasse e eles renascessem livres, para além dos laços de conveniência:

O passado está extinto. Estes onze meses, não fomos nós que os vivemos, mas aqueles que se acabam de separar, e para sempre. Não sou mais sua mulher; o senhor não é mais meu marido. Somos dois estranhos. Não é verdade? (S, p. 182)

Só após o rompimento do contrato é que Aurélia se rende ao amor. Na realidade, é o amor que faz com que Aurélia quebre o antigo acordo e inicie um outro tipo de experiência baseada nas razões do coração:

Pois bem, agora ajoelho-me a teus pés, Fernando, e suplico-te que aceites meu amor, este amor que nunca deixou de ser teu, ainda quando mais cruelmente ofendia-te. ( $S$, p. 182)

Dessa forma, desfaz-se a contradição e se torna possível a leitura coerente de que em Senhora há evidentemente uma crítica à sociedade burguesa do mercado matrimonial, assim como também há a possibilidade de sublimação do amor dentro desta mesma realidade referencialmente criticada. Isso não é paradoxal, sobretudo se compreendermos que Alencar via - ou era obrigado a ver - no amor uma possível solução à invasão da postura mercantil nos relacionamentos conjugais.

Idealismo? Talvez. Mas não deixa de ser uma tentativa de engajamento contra a decadência dos valores sociais que presenciava. E não é esse o papel do escritor? Segundo Sartre «a função do escritor é fazer com que ninguém possa ignorar o mundo e considerar-se inocente diante dele» (p. 21). «Engajado» (com toda a ousadia da utilização do termo avant la lettre) foi Alencar, ao nos expor o mundo em que vivia, criticando-o e sugerindo um caminho alternativo do amor, que escapasse aos critérios meramente utilitários. Nesse sentido, mais engajado ainda seria Eça de Queirós, por meio de seu Alves \& Cia. Se Alencar usou um discurso moralizante-pedagógico para ensinar a seus contemporâneos que superior é o amor às relações erguidas pelo poder do capital, o caminho trilhado por Eça levar-nos-ia a uma outra direção, mais ousada, mais radicalmente transgressora. 
Em Alves \& Cia, a crítica queirosiana já é de outro timbre, por se pautar não no drama mas no riso. Em seu ensaio "A Decadência do Riso", Eça de Queirós recomenda ao leitor o riso como terapia diante dos vícios da civilização moderna. Como que a antever a teoria da carnavalização de Bakhtin, e adaptando-a à situação finissecular, Eça defende a idéia de que o riso relativiza os valores sociais. Em Alves \& Cia, o humor leve e lúdico é o instrumento utilizado pelo autor para denunciar uma sociedade invadida pelo espírito capitalista que se manifestava inclusive nas relações matrimoniais. Ao contrário do que determinada crítica quer supor, Alves \& Cia não é obra menor se comparada a Os Maias, O Primo Basílio ou O Crime do Padre Amaro, só para citar alguns de seus romances mais famosos. Alves \& Cia também não é exemplo de uma fase - entendida por alguns como reacionária - em que o Eça das críticas vorazes, agora já arrependido e desiludido, teria abandonado o senso crítico. Se Alves \& Cia, assim como A Cidade e as Serras, não pertence à linhagem dos romances de inspiração mais naturalista, reconhecidos por tentarem «dar o choque ao enorme porco adormecido» como ele chamou a pátria, estes livros - estrategicamente diferentes, porém não menos engajados - evidenciam a etapa mais madura e reflexiva de um autor que prefere agora rir a chocar. Nesse sentido, Eça se distancia já por princípio do discurso pedagógico de Alencar. Sobre isso, afirma Lélia Parreira Duarte no importante ensaio "Alves \& Cia, de Eça de Queirós, e Amor \& Cia, de Helvécio Ratton»:

O humor presente em Alves \& Cia certamente tem como objetivo recuperar e fazer crescer esse riso. Principalmente porque acentua dados demonstrativos de que o texto de Eça não se propõe a dar lições ou a colocar o escritor como sacerdote ou salvador. Pois abre caminhos para o gozo e o enriquecimento trazido pelo humor. Humor de quem não coloca em dúvida o que narra e não põe em causa a autoridade de um autor que se pressupõe capaz de ver e fazer ver a verdade. Mas que tem a perspicácia e a sensibilidade de mostrar que a verdade/realidade depende da perspectiva. (P. 104)

Se, em Senhora, Alencar dá à sua crítica um tom que beira o dramático, em Alves \& Cia, Eça não poupa a comicidade. Pelos jogos da ironia, o autor brinca com o dilema de Godofredo, que oscila entre desfazer o casamento e com ele a sociedade financeira, ou acreditar que não houvera adultério, preservando assim não só os negócios, mas também o matrimônio. Analisando atenciosamente Alves é Cia, percebemos que é possível depreender da obra uma estrutura semelhante à de Senhora. Substituindo o juízo moral pelo veio irônico, a narrativa queirosiana permite que também nela vejamos, ainda que sob uma perspectiva diferente, um preço, uma quitação, uma posse e um resgate.

Concordamos que Alves \& Cia é uma narrativa em que se espelham os relacionamentos conjugais e as negociações de trabalho. Como era típico de uma sociedade dominada pelos valores burgueses do capitalismo, nos tempos de 
Godofredo a tranqüilidade familiar significava também a segurança do status e, de certa forma, a sobrevivência do lucro. Lucia Castelo Branco, em Eros Travestido, afirmou a esse respeito que $« \mathrm{O}$ sexo regulamentado mantinha [...] equilíbrio e harmonia de toda uma sociedade» (BRANCO, 1985: 19). Com Godofredo, Ludovina e Machado não foi diferente. Tudo ia muito bem nos negócios de Godofredo e Machado até o marido descobrir - ou supor - que sua esposa o estava traindo com o seu sócio. Com a «possível» revelação de um possível adultério, o esposo traído não só entra em conflito com o sócio, como deseja enfrentá-lo em duelo, o que nos levaria a classificar o adultério de Ludovina como um saldo negativo da firma comercial. Aí estaria o PREÇO, cobrado pela hipocrisia que mantinha controlado o desejo escondido pelos oitocentistas:

E o que viu, santo Deus, deixou-o petrificado, sem respiração, todo o sangue na cabeça, e uma dor viva no coração, que quase o deixou por terra... No canapé de damasco amarelo, diante de uma mesinha, com uma garrafa de vinho, Lulu, de robe de chambre branco, encostava-se abandonada, sobre o ombro dum homem que lhe passava o braço pela cintura, e sorria, contemplando-lhe o perfil, com um olhar afogado em languidez. Tinha o colete desabotoado. E o homem era o Machado. Ao estremecer do reposteiro, Ludovina vira-o, deu um grito, saltou instintivamente para longe do sofá. E Godofredo ouviu aquele grito: mas não se podia mexer, sem saber como, achara-se caído sobre uma cadeira ao pé da porta, e tremia, tremia, como numa sezão, e todo frio. (AC, p. 18 e p. 19)

Sendo o adultério o PREÇO, e um preço alto, já que pode levar à dissolução da sociedade entre Godofredo e Machado, cabe a Godofredo, como bom negociador, a iniciativa de resolver a situação salvando-se do risco de falência. No entanto, atordoado com o desastre conjugal, o caminho escolhido por ele para vencer o risco financeiro é menos racional do que passional. Por isso, como QUITAÇÃO, o que se tem é um desejo de vingança: «E através do sangue que lhe fervia na cabeça, as suas idéias fixavam-se, decidia-se a bater-se com o Machado, num duelo de morte.» (AC, p. 22)

Ora, se negócios e amor caminham lado a lado, o affair de Machado e Lulu não trazia conseqüências só ao trabalho, mas também ao coração de Godofredo. Vale salientar que, embora o riso queirosiano seja o elemento que permite a leitura irônica da história de Godofredo, para a personagem sua vida não é cômica, mas profundamente dramática. Do riso, compartilham com o autor apenas os amigos de Godofredo. O marido «traído» - que se julga moralmente ferido - toma POSSE do prejuízo, assumindo, profissional e sentimentalmente, as consequências daquele episódio no sofá: «uma existência abominável» (p. 92). Os amigos, após analisarem seu caso, convencem-no, contudo, de que o adultério não se consumara:

O Vidal dissera que não havia motivo de sangue, porque o que se passara entre Machado e a senhora fora um simples namoro... [...] Era uma brincadeira, era a rir, era a fazer cócegas... (AC, p. 80$)$ 
Ora agora, dizia o Nunes: o que faz um duelo? Compromete a sra. Dona Ludovina, faz crer ao público que houve realmente adultério, torna ridículo o sr. Alves e prejudica a firma comercial... (AC, p. 88)

Godofredo convence-se, então, de que tudo não passara de uma «brincadeira». Reata pois o casamento com Ludovina e mantém a sociedade com Machado. Dessa forma, elimina-se o prejuízo e se realiza o RESGATE. Em lugar de "tornar-se ridículo», Godofredo aprende ele também a rir. Unindo-se aos amigos e, principalmente, a Eça de Queirós, o personagem diz a Machado: "Que coisa prudente é a prudência!» Num final ironicamente feliz, «as duas famílias vivem junto uma da outra - e ao lado uma da outra vão envelhecendo» (p. 119).

Diferente do final de Senhora, o final de Alves \& Cia não apresenta o juízo moral de um autor que, insatisfeito com os valores da sociedade que retrata, encaminha o leitor ao amor como possível solução. Em Alves \& Cia, seja por perceber que o capitalismo não melhorara a humanidade, seja por não suportar a hipocrisia da sociedade, o fato é que Eça de Queirós mostra-nos o humor como um outro modo de olhar os fatos. Em vez da crítica feroz que induz o leitor à intenção do criador, o autor de Os Maias opta agora por relativizar valores, não ordenando, não orientando, apenas sugerindo.

Isso nos remete ao que defendia Roland Barthes em O Prazer do Texto (2002), obra em que o autor distingue «texto de prazer» de «texto de gozo» ${ }^{4}$. $\mathrm{O}$ texto de prazer seria aquele diante do qual há uma recepção instintiva por parte do leitor, um reconhecimento do modelo, uma assimilação passiva. Entretanto, quando o leitor inteligente age criativamente sobre esse mesmo texto, não se satisfazendo com sua emoção agradável, mas transformando essa sensação em aprendizagem, o que se tem não é mais um texto de prazer, e sim um texto de gozo. Diante dessas definições, poderíamos ousar classificando Senhora como um «texto de prazer» enquanto Alves \& Cia, um «texto de gozo», menos por sua radicalidade formal ${ }^{5}$, mas porque desinstala, tira o tapete das certezas, desconcerta os a priori ideológicos, sem se preocupar em reconstituir por sobre os detritos de uma verdade posta em descrédito, qualquer outro valor moral exemplar. Se é verdade que ambas as obras são críticas, é bem verdade também que, enquanto na primeira há um discurso com intenção moralizante, na última existe um discurso irônico que desmonta o mundo, sem tragédia, mas sem deixar pedra sobre pedra do que a convenção estabelecera como moral.

Não há como negar o prazer de leitura propiciado por Senhora, mas, por outro lado, não há como compará-lo ao gozo desinstalador despertado pela leitura da narrativa queirosiana. Enquanto Alencar moraliza, Eça diverte, envolve o leitor e o faz pensar, sem the oferecer, contudo, a resposta gratificante que o reconciliaria inteiramente com os valores instituídos. Entretanto, preferimos ultrapassar qualquer categorização, por acreditarmos - assim como Affonso Romano de 
Sant'Anna - que qualquer tipo de classificação é, afinal, uma ilusão que parte da necessidade humana de racionalizar o vazio, a descontinuidade, em busca constante da continuidade de todo impossível. O modelo que se propõe como acabado, como cobertura da realidade, é, por isso, mentiroso ${ }^{6}$.

Por tudo isso, preferimos deixar ao leitor, terceiro elemento desse nosso discurso, a incumbência de agir inteligentemente sobre este enunciado que tentou precariamente dar conta da trapaça estabelecida pelas enunciações de José de Alencar e Eça de Queirós. Quem sabe assim, as Ludovinas e Aurélias, Godofredos e Fernandos de nosso tempo, que ainda vivem entre arranjos nupciais e contratos sociais, possam fazer dessa leitura aquilo a que Eduardo Lourenço chamou de «autognose» do eu ${ }^{7}$. Até porque, é no limite entre verdade e ficção que se escreve isso que chamamos de Literatura.

${ }^{1}$ Sartre, Jean-Paul. O Que É Literatura? São Paulo: Ática. 2004.

${ }^{2}$ Bakhtin, Mikhail. Problemas da Poética de Dostoievski. São Paulo: Editora Forense Universitária, 2002. Partindo da consideração feita por Luís Felipe Ribeiro em Geometrias do Imaginário (1999), citamos: «Isto nos encaminha, naturalmente, para a teoria do diálogo, conceito central no pensamento de Mikhail Bakhtin. Para ele todo discurso, toda palavra é sempre e necessariamente dialógica. Um discurso se articula em resposta a um outro; numa fala sempre está inscrita outra que a provoca e à qual responde. Não existe comunicação no vazio.»

${ }^{3}$ Utilizaremos as seguintes edições: Queirós, Eça de. Alves \& Cia. Porto Alegre: L\&PM, 1997. Alencar, José de. Senhora. São Paulo: Scipione, 1999. Para as citações das obras usaremos as abreviações $A C$ e $S$.

${ }^{4}$ Explicação dos conceitos barthesianos feita por Lélia Parreira Duarte em «Alves \& Cia, de Eça de Queirós, e Amor \& Cia, de Helvécio Ratton». In: Figuras e Lusofonia. Cleonice Berardinelli. Lisboa: Instituto Camões, 2002.

${ }^{5}$ É importante salientar que, apesar de a radicalidade formal não ser, neste caso, a principal característica que nos leva a classificar Alves \&u Cia como um texto de gozo, não se pode descartar o fato de que é a radicalidade formal que faz da escrita queirosiana um texto de gozo em alguns de seus romances. Um exemplo claro é a citação de A Relíquia (1999), abaixo transcrita:

«À noite, depois do chá, refugiava-me no oratório, como numa fortaleza de santidade, embebia os meus olhos no corpo de ouro de Jesus, pregado na sua linda cruz de pau-preto. Mas então o brilho fulvo do metal precioso ia, pouco a pouco, embaciando, tomava uma alva cor de carne, quente e tenra; a magreza de Messias triste, mostrando os ossos, arredondava-se em formas divinamente cheias e belas; por entre a coroa de espinhos, desenrolavam-se lascivos anéis de cabelos crespos e negros; no peito, sobre as duas chagas, levantavam-se, rijos, esplêndidos seios de mulher, com um botãozinho de rosa na ponta; - e era ela, a minha Adélia, que assim estava no alto da cruz, nua, soberba, risonha, vitoriosa, profanando o altar, com os braços abertos para mim!»

${ }^{6}$ Sant'Anna, Afonso Romano. Análise Estrutural de Romances Brasileiros. São Paulo: Ática, 1990.

${ }^{7}$ Lourenço, Eduardo. O Labirinto da Saudade. Psicanálise Mítica do destino Português. Lisboa: Publicações Dom Quixote, 1978. 


\section{BiBLIOGRAFIA}

1. Alencar, José de. Senhora. São Paulo: Scipione, 1999.

2. Bakhtin, Mikhail. Problemas da Poética de Dostoievski. São Paulo: Editora Forense Universitária, 2002.

3. Barthes, Roland. Aula. São Paulo: Cultrix,1978.

4. Barthes, Roland. O Prazer do Texto. São Paulo: Ed. Perspectiva, 2002.

5. Bosi, Alfredo. História Concisa da Literatura Brasileira. São Paulo: Cultrix, 1994.

6. Branco, Lucia Castelo. Eros Travestido. Um Estudo do Erotismo no Realismo Burguês Brasileiro. Belo Horizonte: Ed. UFMG, 1985.

7. Candido, Antonio. Formação da Literatura Brasileira. Belo Horizonte: Ed. Itatiaia, 2000.

8. Duarte, Lélia Parreira. «Alves \& Cia, de Eça de Queirós, e Amor \& Cia, de Helvécio Ratton». In: Figuras e Lusofonia. Cleonice Berardinelli. Lisboa: Instituto Camões, 2002.

9. Gay, Peter. A experiência Burguesa da Rainha Vitória a Freud. Vols I, II e III. São Paulo: Companhia das Letras. 1998, 1990, 1995.

10. Grossegesse, Orlando. «Sobre a re-carnavalização em A cidade e as Serras». In: Reis, Carlos. Queirosiana. Estudos sobre Eça de Queirós e a Sua Geração, n. ${ }^{\circ}$ 1. Coimbra: 1991.

11. Helena, Lucia. A Solidão Tropical: o Brasil de Alencar e da Modernidade. Porto Alegre: EDIPUCRS, 2006.

12. Lourenço, Eduardo. O Labirinto da Saudade. Psicanálise Mítica do Destino Português. Lisboa: Publicações Dom Quixote, 1978.

13. Oliveira, Maria Teresa Martins. A Mulher e o Adultério nos Romances O Primo Basílio de Eça de Queirós e Effi Briest de Theodor Fontane. Coimbra: Livraria Minerva / Centro Interuniversitário de Estudos Germanísticos / Faculdade de Letras da Universidade do Porto, 2000.

14. Queirós, Eça de. «A Decadência do Riso». In: Notas Contemporâneas. Lisboa: Edição Livros do Brasil, 2000.

15. Queirós, Eça de. Alves \& Cia. Porto Alegre: L\&PM, 1997.

16. Queirós, Eça de. A Relíquia. Lisboa: Livros do Brasil, 1999.

17. Ribeiro, Luis Filipe. Geometrias do Imaginário. Galiza: Laiovento, 1999

18. Sant'Anna, Afonso Romano. Análise Estrutural de Romances Brasileiros. São Paulo: Ática, 1990

19. Santos, João Camilo. «Eça de Queirós: coerência e evolução». In: Estudos Portugueses e Africanos, n. ${ }^{\circ}$ 41. São Paulo: Ed. Unicamp, 2003.

20. Sartre, Jean-Paul. O Que É Literatura? São Paulo: Ática. 2004.

21. Sennett, Richard. O Declínio do Homem Público. As Tiranias da Intimidade. São Paulo: Companhia das Letras, 1988. 